MINING

UDC 004.891:622.232

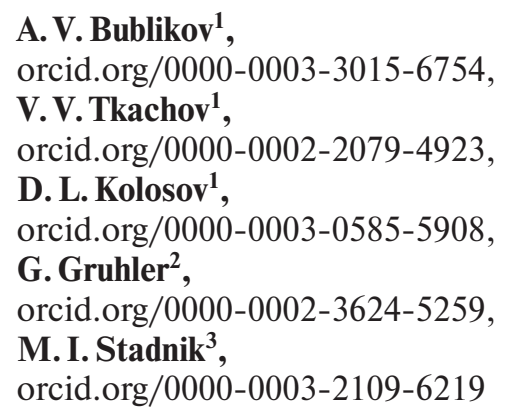

https://doi.org/10.33271/nvngu/2021-3/005

1 - Dnipro University of Technology, Dnipro, Ukraine, e-mail: bublikov.a.v@nmu.one

2 - Reutlingen University, Reutlingen, Federal Republic of Germany

3 - Vinnytsia National Agrarian University, Vinnytsia, Ukraine

\title{
AUTOMATION OF THE CONTROL PROCESS BY THE SHEARER DRUM IN TERMS OF COAL SEAM HYPSOMETRY
}

Purpose. To develop a method for synthesizing a fuzzy automatic control system for a shearer drum in terms of coal seam hypsometry basing on the information criterion of the beginning of rock cutting-off by the drum to reduce ash content of the extracted coal.

Methodology. Taking into consideration peculiarities of determining a distinct information criterion of the beginning of rock cutting-off by the drum and regularities of its variations during the shearer operation, a fuzzy inference algorithm is developed for a system of fuzzy automatic drum control in terms of seam hypsometry. In this context, rules of fuzzy productions, parameters of the membership functions of terms of the output linguistic variable system, and fuzzy operations are substantiated according to the recommendations of a classic Mamdani fuzzy inference algorithm. Studies are carried out to analyze the efficiency of the proposed fuzzy inference algorithm basing on the introduced relative parameter of the number of effective control actions formed by the fuzzy control system. Simulation modeling makes it possible to perform comparative analysis of the efficiency of the drum control.

Findings. In the course of research, an algorithm of fuzzy control of the shearer's upper drum in terms of coal seam hypsometry has been developed basing on the determination of direct and inverse transfer from coal breaking near the seam roof by the shearer drum to rock breaking with the help of statistical analysis of the stator power of a cutting drive motor.

Originality. For the first time, a method of synthesis of fuzzy automatic control of the drum in terms of seam hypsometry has been proposed.

Practical value. The proposed method is the theoretical basis to solve important scientific and applied problem of the automation of the coal shearer drum in terms of seam hypsometry to reduce ash content of the produced coal.

Keywords: coal shearer, fuzzy inference algorithm, coal seam hypsometry, coal ash content

Introduction. Efficient development of domestic coal reserves is one of the conditions to solve a problem of energy security of Ukraine. However, Ukrainian specific energy consumption for coal extraction is one of the highest in the world [1]. Moreover, such qualitative coal parameters as ash content and amount of fines are rather overestimated [2]. That is caused not only by complex mining and geological conditions but also by insufficient use of innovative developments aimed at improving the coal mining technologies.

Taking into consideration significant power-to-weight ratio of mining machines due to considerable mechanical efforts generated by them [3] and a great amount of coal extracted in mines, even insignificant decrease in specific energy consumption for coal extraction, its ash content or amount of coal fines result in substantial positive economic effect. Thus, increase in the efficiency of mining machines is quite a topical problem; and improvement of morally obsolete methods and algorithms to automate control processes

(C) Bublikov A.V., Tkachov V.V., Kolosov D. L., Gruhler G., Stadnik M. I., 2021 for those mining machines is one of the effective solutions of that problem.

Unsolved problem. Nowadays, mining machines are controlled objects that have highly developed information and electronic components making it possible to store data concerning dozens of machine parameters. However, the data is used only to provide the operating mode set by an operator. Thus, lack of proper algorithms to analyze the obtained information during the mining machine operation as well as nonavailability of certain algorithms to form control actions based on the real-time processing of that information is the reason why the equipment control in the mining industry is inefficient due to a human factor.

The example is an operator's inability to assess rapidly the loading level of an armoured conveyer and change correspondingly the velocity of its traction drum, which results in the fact that the conveyor operates with considerably increased specific power consumption due to its underloading. According to the research results in [1], lack of velocity control of a traction drum of an armoured conveyor in the freight flow function results in more than twofold increase in average daily 
specific power consumption for coal transportation along the face depending on the underloading coefficient.

Consider another example. Nowadays, in terms of thin coal layers and due to insignificant loading productivity of a drum, the operator-controlled coal shearers operate on the brink of jamming [4]. That makes an operator record the drum jamming with certain time lag; thus, there are periodical (within $40-50 \%$ of all time) considerable increases (by $30-$ $40 \%$ ) in specific power consumption for coal extraction.

Consequently, implementation of different methods and algorithms for automation of mining machinery control will make it possible to improve substantially the coal extraction efficiency at mining enterprises.

Literature review. Mining machines of new generation are sophisticated mechatronic complexes combining components of different physical nature on the basis of synergetic approach. Besides, they are characterized by complicated interaction with the external medium $[5,6]$. As a rule, in terms of controlled objects of such class, specialists use methods of synthesis of control systems on the basis of so-called "intellectual" technologies from the artificial intelligent field with the prevailing expert systems, fuzzy logic, artificial neural networks, genetic algorithms, and agent-based software. In this context, combination of several known methodological approaches is often applied.

For instance, papers [7, 8] develop two-level adaptive strategy of the optimization that involves simultaneous study on well drilling while extracting different mineral and technological iron ore types and improvement of that process control with the help of self-adaptive fuzzy system.

An example of the use of intellectual control systems in mining industry is represented by the developed system of automated power flow control in terms of underground iron ore extraction with the use of several strategies and channels of control based on fuzzy logic [9].

As for the coal shearers, they are quite well studied as the controlled objects being characterized by relative simplicity and unchangeable rule base that connects the operator's actions with the list of situations occurring while controlling. On the one hand, difficulties with the sharer control are stipulated by the dynamic and unexpected time changes in the sharers' operating modes; on the other hand, the difficulties are caused by the impossibility to identify unambiguously those modes basing on the analysis of sensor signals within a short period of time. Taking that into consideration, to solve the problem of control automation of a shearer, it is necessary to implement expert systems that involve fuzzy logic to recognize different situations according to the approach proposed in paper [10].

Unsolved aspects of the problem. Due to a complicated nature of coal mass breaking by the shearer drum and inconstant mining and geological properties of rock and coal, today there are no methods for direct measuring of rock-coal boundary. In this context, different techniques are being implemented actively aimed at indirect identifying of that boundary basing on the measurement and analysis of changes in physical values that characterize the rock and coal properties implicitly. An example of such an approach is represented by the determination of rock-coal boundary basing on the analysis of acoustic signal near an upper drum with the help of wavelet-neural network in terms of using swarm algorithm of minimizing errors of the event identification [11]. Paper [12] deals with the solution of similar problem: identification by the intellectual system of the rock cutting-off near the seam roof by an upper shearer drum. However, the paper solves that problem by analysing vibration signals measured at different points of a shearer's cutting drive. In this context, swarm optimization algorithms are applied to identify the events as well.

In future, the results obtained in papers [11, 12] may be used as components of a complex information criterion of availability or nonavailability of rock cutting-off by a drum near the seam roof. However, the papers highlight that the task of efficient recognition of rock cutting-off by the intellectual system of the shearer's control system for any conditions of the shearer operation has not been solved completely, requiring its further study.

One more approach to the solution of the task of automation of shearer drum control in terms of seam hypsometry is described in paper [13]. It is based on a new method of coal seam hypsometry memorizing by the intellectual system of shearer control, according to which certain changes in ground angle inclination are taken into account as the important factor effecting the determination of seam thickness in terms of the drum height. In this context, while forming the drum's lifting height setting on the basis of the previously recorded data on seam hypsometry changes along the face, a method of fuzzy optimization is applied. Disadvantage of the described shearer control technique is in the fact that staff is not completely eliminated from the face as an operator should carry out periodic system learning as the face is advancing.

Methods. Taking into consideration peculiarities of determination of distinct information criterion of the beginning of rock cutting-off by a drum and regularities of its changes in the process of shearer operation, a fuzzy inference algorithm for the system of fuzzy automatic control of a drum in terms of seam hypsometry is created. In this context, rules of fuzzy productions, parameters of the membership functions of terms of the output linguistic variable system, and fuzzy operations are substantiated according to the recommendations of a classic Mamdani fuzzy inference algorithm. The efficiency of the proposed fuzzy inference algorithm is analysed on the basis of the introduced relative parameter of the number of effective control actions formed by the fuzzy control system. Simulation modeling makes it possible to perform comparative analysis of the drum control efficiency in terms of seam hypsometry by an operator and with the use of the proposed fuzzy inference algorithm.

Purpose. The research objective is to reduce ash content of coal by developing a fuzzy inference algorithm to automate the control of a drum in terms of coal seam hypsometry basing on the information criterion of the beginning of rock cutting-off by a drum.

Results. Fuzzy automated control of a shearer drum in terms of coal seam hypsometry is to be developed basing on the method proposed in [10]. According to the method, basic operating modes of the controlled object and their characteristics are to be discussed first with the specification of indicative events and information criteria making it possible for the control system to identify the characteristics of operating modes of the controlled object.

The mentioned procedures are performed in paper [14] relative to the process of a shearer drum in terms of seam hypsometry. The research emphasizes such characteristics of the material breaking by a drum near the seam roof as "Coal breaking" and "Rock breaking". However, with the viewpoint on the fact that the information criterion helps identify only changes in a material type being broken by the drum at its different heights, the input linguistic variable of a fuzzy automatic control system "Changes in material type being broken by the drum near the seam roof" and the output one "Changes in the drum's lifting height" are proposed. In this regard, a scheme of fuzzy inference algorithm for the drum's fuzzy control system and its flow diagram coincide with the similar schematic in paper [10] as the identical approach is used to develop the system.

According to Fig. 3 in paper [10], a fuzzy inference algorithm starts with the checking of the conditions as for the data accumulation to determine a fuzzy information criterion of nonavailability of the beginning of rock cutting-off by a drum (block 2). As for the process of organ control in terms of seam hypsometry, such a condition is represented by the completion of formation of two samplings of stator power values of the shearer's cutting drive motor during two successive lifting movements of the drum [14]. 
Let us substantiate the values of drum lifting for the occurrence of distinct regularity in the information signal changes, basing on which the beginning of rock cutting-off by the drum is identified. On the one hand, that value should be as small as possible to minimize the thickness of rock layer being broken by the drum. On the other hand, it should be large enough for its recognition on the basis of the criterion of the beginning of rock cutting-off by the drum proposed in [14].

Paper [14] proves that the regularity in the information signal, being the basis to identify the beginning of rock cuttingoff by the drum, appears mostly within the narrow band from 3.1 to $6.2 \mathrm{~Hz}$ at the angle between the velocity vectors of the drum and shearer displacement being not less than $1.27 \mathrm{rad}$. The indicated regularity in the information signal is a onetime signal deviation from its average value in the form of a turned-over parabola. Thus, the upward drum displacements should last at least for the half of the oscillation period with the frequency of $4.7 \mathrm{~Hz}$, i.e. for about $0.1 \mathrm{~s}$. Taking that into account, the simulation model of a subsystem of suspension and displacement of the shearer drum within a vertical plane [15], dependence of the duration of upward displacement of the drum, in terms of the provided inclination angle between the velocity vectors of the drum and shearer displacements being not less than 1.27 rad., upon the drum's lifting height has been studied (Fig. 1).

Basing on the research results represented in Fig. 1, one can conclude the following. To provide distinctive regularity of the information signal change that helps identify the beginning of rock cutting-off by the drum, a change in the drum's lifting height while forming the samplings of the information signal values to determine the information criterion of the beginning of rock cutting-off by the drum, should be not less than $7 \mathrm{~cm}$.

Further, the algorithm of fuzzification of the input variable of the control system developed in [14] helps identify the values of the membership functions of the terms of input linguistic variable "Change in material type" (block 3 in Fig. 3, paper [10]). In this regards, the terms "No change in material type" $(P 1)$ and "Change in material type" $(P 2)$ are introduced.

To aggregate the subterms of the rule base of fuzzy productions, substantiate them on the basis of the analysis of the operator's actions while controlling the upper drum's position within a vertical plane. Since the operator determines the rock cutting-off by the drum visually and the operator can observe the rock-coal boundary only in terms of the drum, the operator changes the drum's position in timely discrete steps by an inconsiderable value with the following long pause until there is the possibility to evaluate the rock-coal boundary in terms of a new position of the drum.

Consequently, the operator's actions may be described with the help of the following expert rules:

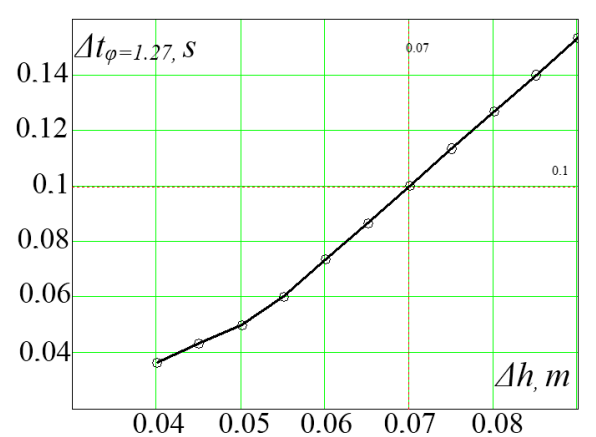

Fig. 1. Dependence of the duration of upward displacement of the drum, in terms of the provided inclination angle between the velocity vectors of the drum and shearer displacements being not less than $1.27 \mathrm{rad}$., upon the drum's lifting height
1. If there is no rock cutting-off by the drum, it should be lifted.

2. If there is no rock cutting-off by the drum, it should be lowered.

However, to reduce probability of erroneous identification of the rock cutting-off by the drum, it is proposed to form a control effect in terms of not only one but several results of that event identification that does not influence the control quality of the drum as the identification time interval (up to $15 \mathrm{sec}$ onds) is by ten folds less within the period of changes in seam hypsometry. Taking that into account as well as considering the proposed terms of the input linguistic variable of the control system, rules of fuzzy productions will be as follows:

1. IF "no change in material type" AND "no change in material type before", THEN "lifting height of the drum increases".

2. IF "no change in material type" AND "change in material type before", THEN "no change in lifting height of the drum".

3. IF "change in material type" AND "no change in material type before", THEN "no change in lifting height of the drum".

4. IF "change in material type" AND "change in material type before", THEN "lifting height of the drum decreases".

According to the formulated rule base of fuzzy productions, the following terms are added to the terms of the output linguistic variables of the control system: "no change in material type before" $(P 3)$ and "change in material type before" $(P 4)$. As for the output linguistic variable of the control system, the following terms are added: "lifting height of the drum increases" $(Z 1)$, "no change in lifting height of the drum" $(Z 2)$, "lifting height of the drum decreases" $(Z 3)$.

Results of the criterion fuzzification in the form of membership function values $\mu_{P 1}$ and $\mu_{P 2}$ are the initial data to aggregate the subconditions of the rule base of fuzzy productions (block 4 in Fig. 3, paper [10]). Under condition of the aggregation of subconditions of the rule base of the drum's fuzzy control system in terms of seam hypsometry and taking into account the uniform information criterion, truth degrees of subconditions $b_{i}^{\prime}$ will be equal to the corresponding membership functions $\mu_{i}$

$$
b_{1}^{\prime}=\mu_{P 1} ; \quad b_{2}^{\prime}=\mu_{P 2} .
$$

Take the truth degree of the subconditions "(no) change in material type before" as the one equal to the truth degree of the subconditions "(no) change in material type" at the previous step of fuzzy inference

$$
b_{3}^{\prime}(k)=b_{1}^{\prime}(k-1) ; \quad b_{4}^{\prime}(k)=b_{2}^{\prime}(k-1) .
$$

After aggregation of the conditions, block 4 in Fig. 3 in paper [10] also shows a procedure of aggregation of the conditions of fuzzy productions of the rule base, during which the truth degrees $b^{\prime \prime}$ of all the conditions of the rule base of the drum's fuzzy control system in terms of seam hypsometry are determined. Taking into consideration the structure of fuzzy expressions under conditions of the rule base represented before, we use the min-conjunction operation (numeration of the truth degree of the conditions $b^{\prime \prime}$ coincide with the rule number) in the formulas to determine the truth degree of $b^{\prime \prime}$ conditions for each rule

$$
\begin{aligned}
b_{1}^{\prime \prime}=\min \left(b_{1}^{\prime}, b_{3}^{\prime}\right) ; & b_{2}^{\prime \prime}=\min \left(b_{1}^{\prime}, b_{4}^{\prime}\right) ; \\
b_{3}^{\prime \prime}=\min \left(b_{2}^{\prime}, b_{3}^{\prime}\right) ; & b_{4}^{\prime \prime}=\min \left(b_{2}^{\prime}, b_{4}^{\prime}\right) .
\end{aligned}
$$

Next, according to the algorithm in Fig. 3 in paper [10], we formulate the conditions of changes and nonavailability of changes in the operating mode for the drum's system of fuzzy control in terms of seam hypsometry. 
Take the fact of meeting one of the subconditions of the rule base of fuzzy inductions that corresponds to the event of change in characteristics of the shearer's operating mode, as the conditions of changes in the shearer's operating mode with the truth degree of 0.5 and higher. Correspondingly, the formula for the conditions of changes in the shearer's operating mode (block 5, Fig. 3 in paper [10]) will be as follows

$$
b_{1}^{\prime} \geq 0.5 ; \quad \text { or } \quad b_{2}^{\prime} \geq 0.5 ; \quad \text { or } \quad b_{3}^{\prime} \geq 0.5 ; \quad \text { or } \quad b_{4}^{\prime} \geq 0.5 .
$$

Rules of fuzzy productions for the system of fuzzy control are formulated so that there is no separate term associated with zero variations in the operating mode. In addition, in view of the uniform information criterion, there is no need to check the condition of filling of the auxiliary samplings. Thus, in this case there is no condition of zero variations in the operating mode.

In terms of the procedure of activation of subconclusions (block 7 in Fig. 3, paper [10]), the truth degrees $c_{i}$ and values of the membership functions $\mu c_{i}$ are determined for each conclusion of the fuzzy production rules of the rule base of a fuzzy control system. In this regards, in terms of determination of the truth degree of conditions, one can observe the aggregation of identical conclusions basing on the fuzzy disjunction operation with taking all the weight coefficients as being equal to a unit

$$
c_{1}=b_{1}^{\prime \prime} ; \quad c_{2}=\max \left(b_{2}^{\prime \prime}, b_{3}^{\prime \prime}\right) ; \quad c_{3}=b_{4}^{\prime \prime},
$$

where $c_{1}$ is truth degree of the conclusion "lifting height of the drum increases"; $c_{2}$ is truth degree of the conditions "no change in lifting height of the drum"; $c_{3}$ is truth degree of the conditions "lifting height of the drum decreases".

The membership functions $\mu c_{i}$ for each $i^{\text {th }}$ conclusion of the fuzzy production rules of the rule base of a fuzzy control system are determined with the help of a min-activation method

$$
\begin{aligned}
& \mu_{c_{1}}(y)=\min \left[c_{1}, \mu_{y_{1}}(y)\right] ; \\
& \mu_{c_{2}}(y)=\min \left[c_{2}, \mu_{y_{2}}(y)\right] ; \\
& \mu_{c_{3}}(y)=\min \left[c_{3}, \mu_{y_{3}}(y)\right],
\end{aligned}
$$

where $y$ is an output explicit variable of a subsystem (in our case - a value of a change in the drum's lifting height $\Delta h$ ); $\mu_{y 1}$ is membership function of the term "lifting height of the drum increases" of the output linguistic variable; $\mu_{y 2}$ is membership function of the term "no change in lifting height of the drum" of the output linguistic variable; $\mu_{y 3}$ is membership function of the term "lifting height of the drum decreases" of the output linguistic variable.

Further, a procedure of the accumulation of conclusions of the fuzzy production rules is carried out taking into consideration the fact that all the conclusions are the characteristics of one output linguistic variable subsystem - change in lifting height of the drum (block 8 in Fig. 3, paper [10]). Basing on the graphs of membership of the terms of an output linguistic variable subsystem (Fig. 5), we accumulate the conclusions of the fuzzy production rules involving a max-aggregation method. As a result, we obtain a value of membership functions $\mu_{y}$ for a linguistic output variable system "Change in lifting height of the drum"

$$
\mu_{y}(\Delta h)=\max \left[\mu_{y_{1}}(\Delta h), \mu_{y_{2}}(\Delta h), \mu_{y_{3}}(\Delta h)\right] .
$$

In terms of defuzzification of the output linguistic variable of a fuzzy control system (block 9 in Fig. 3, paper [10]), the following fact is taken into consideration: a value, by which the lifting height of the drum should be varied while recognizing some specific event, is a distinct value that is known before. It is selected on the basis of maintaining the drum operation near the rock-coal boundary within several procedures of identification of that event. To do that, a value of change in the drum's lifting height should be by several times less than the value of the drum lifting while forming the samplings of information signal values.

Taking into account the available distinct response, by what value it is necessary to change the drum's lifting height in terms of recognition of a certain event, as well as taking into consideration the structure of fuzzy production rules, graphs of the membership functions of the output linguistic variable terms are taken to be triangular with symmetric arrangement relative to the ordinate axis without intersections. A modal value of the membership functions is equal to $15-20 \%$ of the drum's lifting height while forming the samplings with the information signal values; the coefficient of fuzziness is equal to a half of the modal value.

A defuzzification procedure of a linguistic output variable system "Change in lifting height of the drum" is performed involving a method of area centres for discrete sets (block 9 in Fig. 3, paper [10])

$$
\begin{gathered}
\sum_{i=1}^{u} \mu_{y}(\Delta h(i))=\sum_{i=u}^{L} \mu_{y}(\Delta h(i)) ; \\
\Delta h=\Delta h(u),
\end{gathered}
$$

where $\Delta h(i)$ is a vector of the values of the drum's lifting height variation from $(-a-\beta)$ to $(a+\beta)$ with $0.0001 \mathrm{step}, \mathrm{m} ; L$ is dimensionality of the vector $\Delta h(i) ; u$ is index of the vector $\Delta h(i)$, at which the condition of equality of the right and left parts of equation (1) is met.

To analyse the quality of formation of the control action by a fuzzy control system, a relative parameter of the number of formations of adequate control actions by a fuzzy automatic control system with the truth degree of a correct conclusion of the fuzzy production rules being 0.5 and higher is proposed as the criterion, $\%$

$$
R=\frac{\sum_{a=a_{0.5 \min }}^{a_{0.5 \max }} f_{d}(a)}{\sum_{a=a_{\min }}^{a_{\max }} f_{d}(a)} \cdot 100,
$$

where $a$ is a distinct output variable of a fuzzy automatic control system; $a_{\min }$ and $a_{\max }$ are minimum and maximum values of a distinct output variable of a fuzzy automatic control system; $a_{0.5 \min }$ and $a_{0.5 \text { max }}$ are averaged minimum and maximum values of a distinct output variable of the system, at which a condition of exceeding of a correct conclusion of the fuzzy production rules, being 0.5 and higher, by the truth degree is still met; $f_{d}(a)$ is function of density of probability that is defined during the approximation of a normalized histogram of distribution of the values of a distinct output variable of a fuzzy automatic control system. In this regards, the histogram is obtained basing on the sampling with the values of a distinct output variable system, whose length is sufficient enough for the error of determinations of statistic estimates to be less than $5 \%$ (conditions of meeting that requirement is considered below).

In regard to the proposed algorithm of fuzzy conclusion, in case of effective formation of the control action by the system as for the changes in the drum's lifting height, the general view of the histogram of distribution of the values of a distinct output variable system will be similar to the one in Fig. 2, $a$.

Control effects by a fuzzy automatic control system for the operating modes of a shearer as for the increasing and decreasing of the drum's lifting height are formed according to the one-type algorithm and, correspondingly, regularity in the information signal.

That makes it possible to do the following: having specified a similar number of variations in the shearer's operating modes in reverse directions, to transform the output sampling $A$ of the values of the output distinct variable in such a way that the 

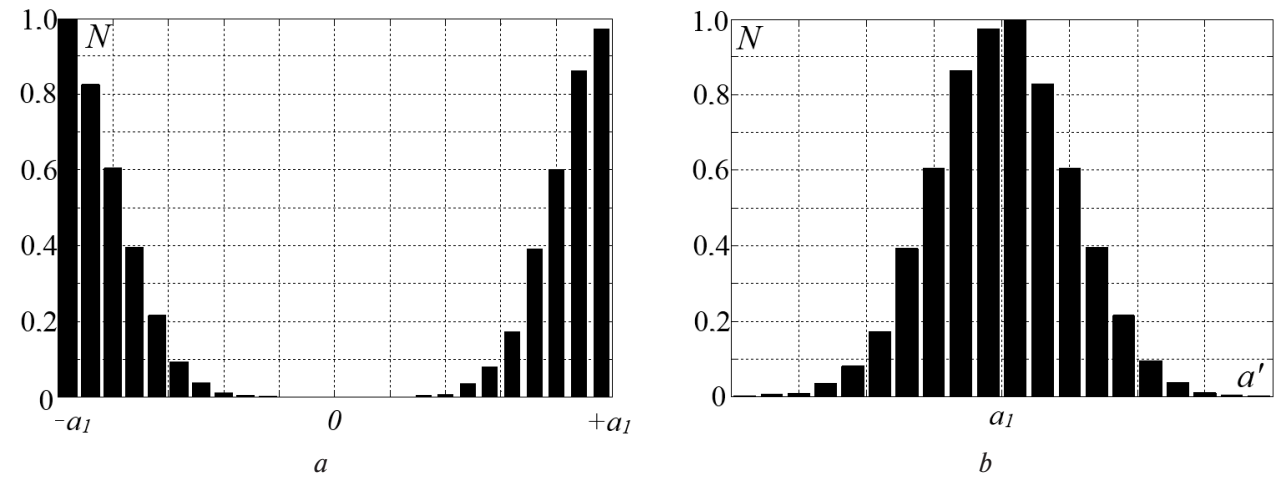

Fig. 2. Normalized histograms of distribution of the distinct output value of a fuzzy automatic control system are obtained:

$a$ - in terms of a standard sampling of that value; $b$ - in terms of the transformed sampling based on formula (3)

distribution of a random value in terms of the transformed sampling $A^{\prime}$ would correspond to one of the classic laws in case of efficient operation of the system.

To do that, two auxiliary samplings are created. One of them contains only positive values of the output distinct variable system (sampling $A_{1}$ ); the other contains only negative ones (sampling $A_{2}$ ).

Further, samplings $A_{1}$ and $A_{2}$ are to be pooled according to the formula

$$
A^{\prime}=A_{1} \cup\left(A_{2 . i}+2 \cdot a_{1}+0.001\right) .
$$

According to (3), a constant $\left(2 \cdot a_{1}+0.001\right)$ is added to each element of vector $A_{2}$; that helps transfer a part of histogram in Fig. 2, $a$ within the zone of negative values of a random value $a$ along the abscissa axis into the zone of its positive values right in terms of value $a_{1}$ (Fig. 2,b).

A condition for pooling the auxiliary samplings $A_{1}$ and $A_{2}$ is preservation of the distribution characters of the output distinct value $a$ of a fuzzy automatic control system for different directions of changes in the shearer's operating mode. That condition is met if we have maximum proximity of ranges of the values of sampling element variations but without their intersection; otherwise, frequencies of the histogram of the pooled sampling $A$ within the intersection zone turn to be much larger comparing to other frequencies. It is the meeting of the indicated conditions that is connected with the introduction of the second summand into (3) in the form of insignificant value 0.001 that is several hundred-fold less than the range of changes in the values of $A_{1}$ and $A_{2}$ sampling elements.

Moreover, to meet the indicated condition of pooling of $A_{1}$ and $A_{2}$ samplings in terms of constructing a histogram of a pooled sampling $A^{\prime}$, it is required that value $a_{1}$ along the abscissa axis be always the boundary between the intervals into which a range of changes in the values of $A^{\prime}$ sampling elements is divided.

If the condition of pooling of the auxiliary samplings $A_{1}$ and $A_{2}$ concerning preservation of the distribution pattern of the output distinct value $a$ of the system for different directions of changes in the shearer's operating mode is met, we will obtain a histogram of the transformed sampling $A^{\prime}$ in case of the efficient decision-making by the system; a general view of the histogram is shown in Fig. 2, $b$.

Auxiliary samplings $A_{1}$ and $A_{2}$ are proposed to be formed basing on the relative deviations of a distinct variable $a_{i}$ from its true value $a_{\text {true }}$, which is taken as being equal to a modal value of the corresponding membership functions as that meets absolutely correct identification of changes in the material type being broken by the drum near the seam roof.

Thus, a simulation model of a subsystem of the drum displacement within the vertical plane [15] helped perform a computational experiment of the drum control in terms of the proposed algorithm for the mining and geological conditions of $C_{5}$ seam of Pavlohradska mine of the Donets Basin, during which the auxiliary samplings was formed according to the formula

$$
\begin{gathered}
A_{1}=\left[-1+\left|\frac{a_{1}-a_{\text {true }}}{a_{\text {true }}}\right|, \ldots, \quad-1+\left|\frac{a_{n}-a_{\text {true }}}{a_{\text {true }}}\right|\right] ; \\
A_{2}=\left[1-\frac{\left|a_{1}-a_{\text {true }}\right|}{a_{\text {true }}}, \ldots, \quad 1-\frac{\left|a_{n}-a_{\text {true }}\right|}{a_{\text {true }}}\right] .
\end{gathered}
$$

Next, basing on (3), a transformed sampling $A^{\prime}$ is to be formed.

Length $n$ of sampling $A$ is defined with the consideration of meeting the condition of no exceedence of $5 \%$ level by the error of determination of statistic estimates of the sampling. The condition for that is inclusion of the main statistic errors of sampling $A$, determining a shape of the graph of distribution of random values (average value $\mu$ and dispersion $\sigma$ ) into a confidence range of $\pm 5 \%$ of their values, determined in terms of the values sampling, with the confident probability of 0.95 . In terms of the process of drum's control according to seam hypsometry, the minimum value of length $n$ of the transformed sampling $A^{\prime}$, at which all inequations in the system of equations are met, is equal to 708 . Consequently, the auxiliary samplings should be of the length not less than 354 elements. Histograms of the auxiliary samplings $A_{1}$ and $A_{2}$ as well as the transformed sampling $A^{\prime}$ are shown in Fig. 3.

Fig. 3, $b$ shows that the view of a histogram of distribution of the transformed sampling $A^{\prime}$ values is characteristic for a normal law of random value distribution. Thus, after pooling the intervals of a histogram in Fig. 3, $b$, within which the frequencies are less than five, test a hypothesis concerning the belonging of the transformed sampling $A^{\prime}$ to a general pool with a normal law of ransom value distribution with the help of xi-criterion

$$
\chi^{2}=\sum_{i=1}^{k} \frac{\left(n_{\text {emp. } i}-n_{\text {theor } . ~}\right)^{2}}{n_{\text {theor } . i}}=10.84,
$$

where $n_{\text {emp }}$ is empiric frequencies of the histogram of distribution of values of the transformed sampling $A^{\prime}$ elements (a histogram with the transparent columns in Fig. $4, a)$; $n_{\text {theor }}$ is theoretical frequencies of the histogram of distribution of values of random variables according to a normal law with average $a=1.001$ and dispersion $\sigma_{a}^{2}=0.0083$ that are determined in terms of the transformed sampling $A^{\prime}$ (a filled histogram in Fig. $4, a) ; k$ is the number of the histogram intervals $(k=15)$.

As for significance level being 0.05 and number of degrees of freedom being 13 , boundary value of xi-criterion is 21.03 . Thus, a hypothesis concerning the belonging of the trans- 

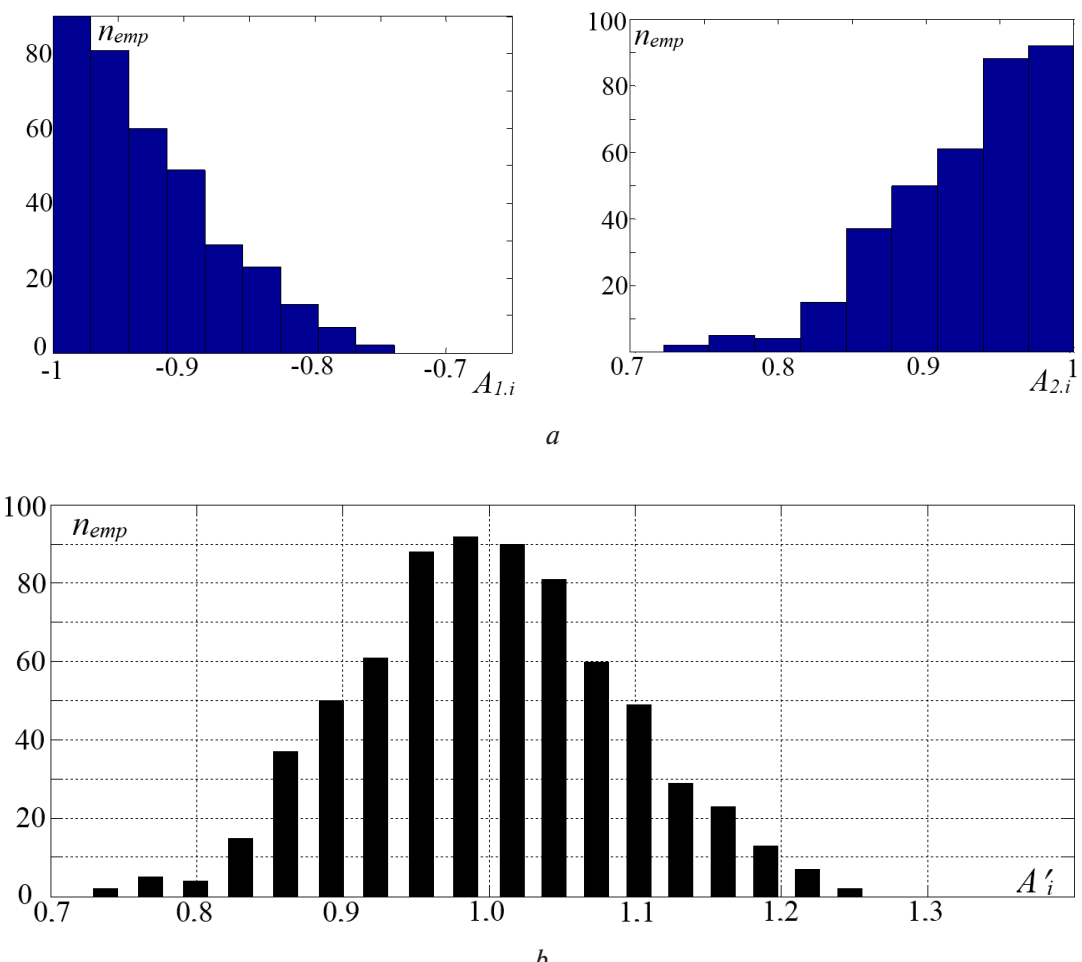

Fig. 3. Histograms of:

$a$ - auxiliary samplings $A_{1}$ and $A_{2} ; b$ - transformed sampling $A^{\prime}$ for the case of periodic increment of rock cutting-off by the shearer's drum near the seam roof

formed sampling $A^{\prime}$ to a general pool with a normal law of distribution is confirmed with the significance level being 0.05 according to the equation

$$
\chi^{2}<\chi_{\alpha ; k-1-r}^{2},
$$

where $\chi_{\alpha ; k-1-r}^{2}$ is boundary value of a xi-criterion with $\alpha$ significance level and $k-1-r$ number of degrees of freedom, where $r$ is the number of statistic estimates determined basing on sampling $A(r=2)$.

Thus, a conclusion can be made concerning the similar nature of decision-making by a fuzzy automatic control system in terms of the available or nonavailable rock cutting-off by the shearer drum near the seam roof. Besides, Fig, 3, $a$ helps conclude that there are no cases when a system makes a wrong decision (the number of elements of the samplings being more than zero for the left Figure and less than zero for the right one is equal to zero).

Further, we test a hypothesis concerning the equality of the average value of the transformed sampling $A^{\prime}$ to a unit that corresponds to the nonavailability of deviation of a distinct output variable of a fuzzy automatic control system from its true value $a_{\text {true }}$ when a system makes absolutely correct decisions.

To do that, Student's t-test is calculated according to the formula

$$
|t|=\frac{\left|\bar{a}-a_{\text {true }}\right|}{\sigma_{a}} \cdot \sqrt{n}=\frac{|1.001-1|}{\sqrt{0.0083}} \cdot \sqrt{708}=0.28 .
$$

In terms of the significance level being 0.05 and the number of degrees of freedom being 707, the t-test boundary value is 1.963 . Thus a hypothesis concerning the equality of average value of the transformed sampling $A^{\prime}$ to a unit is confirmed with the significance level being 0.05 .

To identify the number of cases of efficient decision-making by a fuzzy automatic system controlling the drum in terms of seam hypsometry, we use (2) to calculate a relative parameter of the number of efficient decision-making cases by the system. To do that, we performed approximation of the normalized histogram of the transformed sampling $A^{\prime}$, whose average value and dispersion do not differ from the true statistic estimates by more than $5 \%$ that corresponds to a normal distribution law

$$
f_{d}(a)=\frac{1}{\sigma_{a} \cdot \sqrt{2 \cdot \pi}} \cdot e^{\frac{-(a-\bar{a})^{2}}{2 \cdot \sigma_{a}^{2}}} .
$$

The approximation result is shown in Fig. $4, b$. In this context, the following parameters of a probability-density function are obtained $f_{d}(a): a=0.996$ and $\sigma_{a}=0.0084$.

Taking into consideration the evaluation of the efficiency of the system's decision-making in terms of relative deviation of a distinct output variation of the system from its true value, the results of computational experiments made it possible to identify the left boundary of discrete integration in a nominator of formula (2), being $a_{0.5 \min }=0.84$, and the right one, being $a_{0.5 \max }=1.15$, for a case of periodic occurrence of rock cuttingoff by the shearer drum. Then, a relative parameter of the number of efficient decision-making cases by a fuzzy automatic system of shearer drum control in terms of seam hypsometry is calculated according to the formula, $\%$

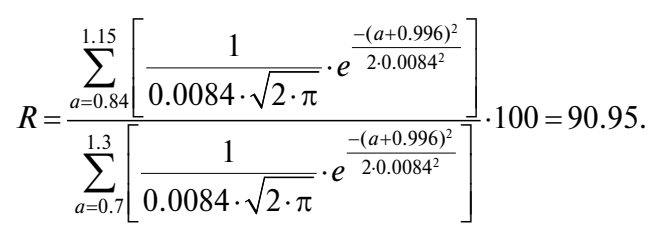

Thus, the results of computational experiments help draw a conclusion that making decisions (with the degree of truth of a correct conclusion of the fuzzy production rules being more than 0.5 ) by a fuzzy automatic system to control a shearer drum in terms of seam hypsometry is efficient in $90.95 \%$ of all cases.

To prove the efficiency of the proposed algorithm of a fuzzy automatic system to control a shearer drum in terms of seam hypsometry, a modeling of this process was performed 


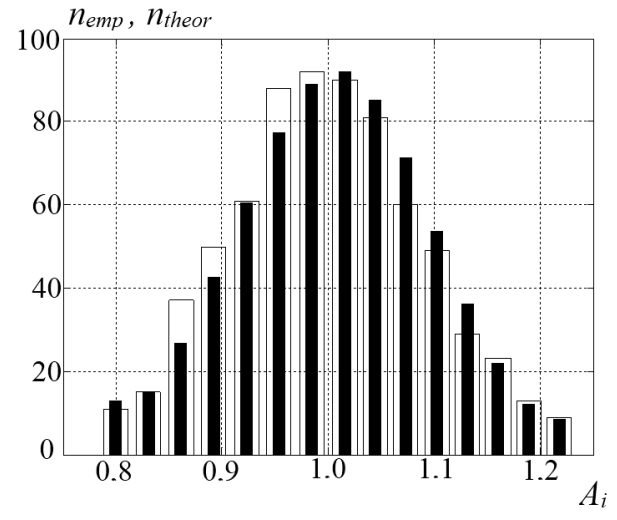

$a$

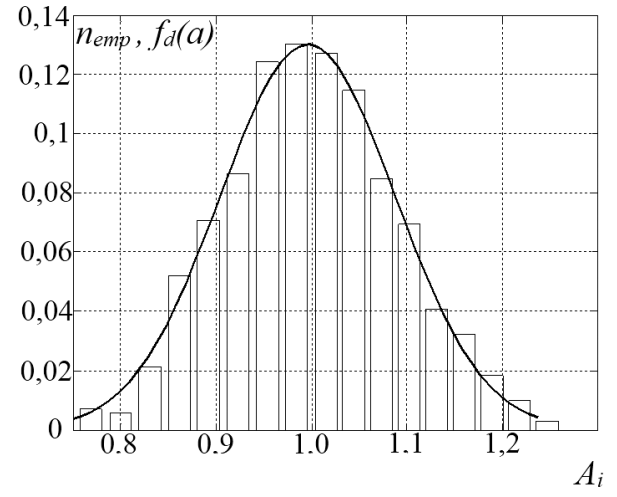

$b$

Fig. 4. Histograms of distribution of the values of the transformed sampling $A^{\prime}$ elements (for the cases of rock cutting-off by the drum) with empiric (transparent columns) and theoretical (filled columns) frequencies ( $a$ ) and a result of approximation of a normalized histogram of distribution of the values of the transformed sampling $A^{\prime}$ elements $(b)$

under conditions of automatic control of the drum and its control by an operator (Fig. 5). The computational experiment was carried out for the mining and geological conditions of $\mathrm{C}_{5}$ seam of Pavlohradska mine of the Donets Basin.

The model simulating the operator's actions is based on the relay law of control; however, in this context, the upper and lower boundaries of the relay characteristics are random values as well as the control action. Besides, one takes into consideration the information time lag as for the meeting the conditions of changes in control action due to impossibility to identify the cutting-off by an operator immediately within the zone of drum operation. The parameters of the model to simulate operator's actions are determined basing on the parametric optimization of a constituent of an empiric autocorrelation function of the cutting drive engine capacity that is connected with the rock cutting-off by the drum near the seam roof.

Fig. 5, $a$ confirms that the variation of the drum's lifting height, while being controlled by an operator, occurs far less frequently; in terms of greater rock cutting-off by the drum, maximum cutting-off value is $9.8 \mathrm{~cm}$, and average value is $6.1 \mathrm{~cm}$. Namely, in terms of using the proposed algorithm of the drum control, the parameters of maximum and average values of rock cutting-off by the drum are by an order less - by 1.75 and 2.7 times respectively. The ash content calculated according to the results of a computational experiment, when an operator controls the drum in terms of hypsometry, is $25.4 \%$. If we subtract parent ash of a seam being $12 \%$, we will get deterioration of the coal ash content due to rock cutting-off near the seam roof by $13.4 \%$, being a much worse parameter comparing with the case of using the proposed algorithm of the drum control $(0.51 \%)$.

If we compare specific power consumption for coal and rock breaking (Fig. 5, $b$ ), they are roughly the same. Specific power consumption for the cases of drum control by an operator within some time intervals are less, which is connected with the consideration of specific energy consumption of the broken rock in the calculation formula (correspondingly, the productivity increases resulting in the decreasing specific power consumption). When seam thickness decreases, a rock share in the general mass becomes greater; with the consideration of its higher strength by $17 \%$ that requires more energy for rock breaking near the roof. At such moments, time intervals in Fig. 5, $b$ show that specific power consumption for the cases of drum control by an operator become longer comparing to the use of the proposed algorithm for the drum control.

Generally, for the case of drum control by an operator, average specific power consumption for rock and coal breaking is
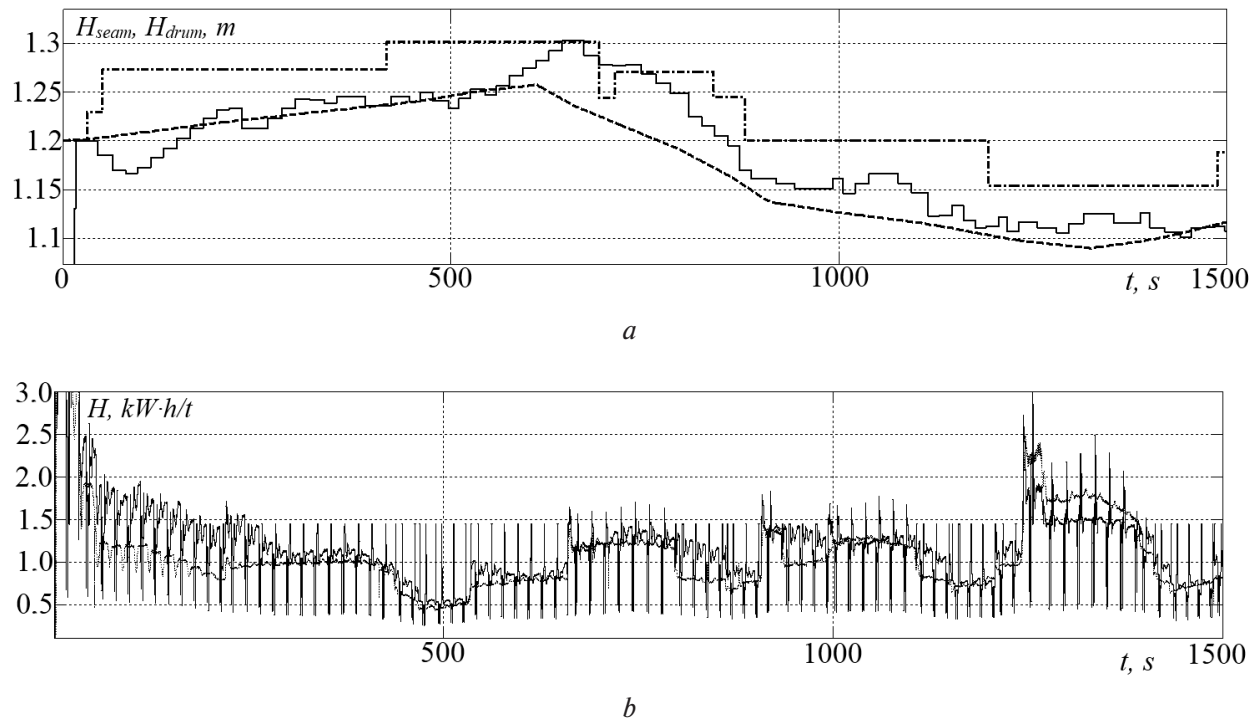

Fig. 5. Time changes in:

a - coal seam thickness (dotted line) and spatial position of the upper point of the drum in terms of its control by an operator (dash-dotted line) and with the use of the proposed algorithm of the shearer drum control (solid line); $b$-specific power consumption for coal mining in terms of control by an operator (dotted line) and with the use of the proposed algorithm of the shearer drum control (solid line) 
$1.03 \mathrm{~kW} \cdot \mathrm{h} / \mathrm{t}$, being by $5.8 \%$ less comparing with the use of the proposed algorithm to control the drum. In this context, specific power consumption is determined according to the formula, $\mathrm{kW} \cdot \mathrm{h} / \mathrm{t}$

$$
\bar{W}=\frac{\bar{P}}{\gamma \cdot \bar{h} \cdot B \cdot \bar{V} \cdot 60}
$$

where $P$ is average power consumed by an electric motor of the upper drum drive, $\mathrm{kW}, h$ is average height of the upper drum lifting within the averaging time interval, $\mathrm{m}$.

However, if we substitute a difference between seam thickness and drum diameter instead of $h$ parameter in (4), we obtain specific power consumption used only for a coal band near the roof seam. In terms of the case of using the proposed algorithm for the drum control, they are $1.18 \mathrm{~kW} \cdot \mathrm{h} / \mathrm{t}$; as for the case of the drum control by an operator in terms of seam hypsometry, they are $1.68 \mathrm{~kW} \cdot \mathrm{h} / \mathrm{t}$, being by $42.4 \%$ more.

Thus, use of the proposed algorithm of the shearer drum control helps prevent considerable rock cutting-off near the seam roof; specific consumption for coal breaking as well as ash content decreases since electric energy is not consumed for needless operations - breaking of the unnecessary coal band near the seam roof.

Conclusions. The fuzzy inference algorithm of a system of fuzzy automatic control of the shearer drum in terms of seam hypsometry is based on Mamdani algorithm with the following modifications:

- membership functions of the terms of an input linguistic variable of a control system are represented by the functions obtained as a result of approximation of histograms of the information criterion distribution values;

- taking into account the fact that an information criterion does not allow identifying rock cutting-off at both stages of the drum's upward displacement and reducing the first-order probability error while identifying rock cutting-off, a modal value of the membership function of an output linguistic variable is taken to be by several times less than the time-related step change value of the drum's lifting height to create the indicative event. That provides the development of a unique regularity in the information signal that is peculiar only for the rock cutting-off by the drum near the seam roof not at one but at 5-7 steps of the system's decision- making;

- owing to the fact that seam hypsometry varies in space much more slowly than in time, the identification of rock cutting-off by the drum requires that the algorithm of the system's decision-making to control the drum in terms of seam hypsometry should be capable of making decisions concerning certain changes in the drum position in terms of the fact that a unique regularity in the information signal occurs not once but several times successively. That is provided by introducing separate terms for the input linguistic variable of the system "were in ...mode before" and complex conditions in the rule base of fuzzy productions of the system like "were in rock-breaking mode before" AND "are in rock-breaking mode now". Owing to that, probability of erroneous identification of the beginning of rock cutting-off by the shearer drum decreases.

Studies on the process of the coal shearer drum control involving the proposed fuzzy inference algorithm have proved its efficiency - the index of the number of effective decisions made by a fuzzy automatic control system is more than $90 \%$, and ash content of coal comparing to the drum control by an operator has decreased by $12.9 \%$ having exceeded the parent ash content of the seam by only $0.51 \%$.

The method proposed in the paper is a theoretical basis to solve an important scientific and applied problem of the automation of a shearer drum control in terms of coal seam hypsometry.

\section{References.}

1. Stadnik, M., Semenchenko, D., Semenchenko, A., Belytsky, P., Virych, S., \& Tkachov, V. (2019). Improving energy efficiency of coal transportation by adjusting the speeds of a combine and a mine face conveyor. Eastern-European Journal of Enterprise Technologies, 1, 6070. https://doi.org/10.15587/1729-4061.2019.156121.

2. Małkowski, P., \& Tymoshenko, Ye. (2018). The quality of coal in Poland, Russia and Ukraine and its effect on dust emission. Technical transactions, 9, 1-21. https://doi.org/10.4467/2353737xct.18.138.8977. 3. Samorodov, V., Bondarenko, A., Taran, I., \& Klymenko, I. (2020). Power flows in a hydrostatic-mechanical transmission of a mining locomotive during the braking process. Transport Problems, 15, 17-28. https://doi.org/10.21307/tp-2020-030.

4. Dinh, V.Ch., Nguyen, K. L., Nguyen, V.X., \& Le, T. B. (2020). Influence of the winding angle of auger shearer-loader on the efficiency of coal loading on the downhole conveyor. Ugol', (1), 46-50. https:// doi.org/10.18796/0041-5790-2020-1-46-50.

5. Sdvyzhkova, O., Golovko, Y., Dubytska, M., \& Klymenko, D. (2016). Studying a crack initiation in terms of elastic oscillations in stress strain rock mass. Mining of Mineral Deposits, 10(2), 72-77. https://doi.org/10.15407/mining10.02.072.

6. Sdvyzhkova, O., Babets, D., Moldabayev, S., Rysbekov, K., \& Sarybayev, M. (2020). Mathematical modeling a stochastic variation of rock properties at an excavation design. International Multidisciplinary Scientific GeoConference: SGEM, 20(1.2), https://doi.org/10.5593/ sgem2020/1.2/s03.021.

7. Tron, V., Tsokurenko, O., Paraniuk, D., \& Haponenko, I. (2019). Formation of the adaptive fuzzy model of the rock geological structure for exploratory drilling. E3S Web of Conferences, 123, 01037. https:// doi.org/10.1051/e3sconf/201912301037.

8. Morkun, V., Morkun, N., Tron, V., Paraniuk, D., \& Sulyma, T. (2019). Adaptive control of drilling by identifying parameters of object model under nonstationarity conditions. Mining of Mineral Deposits, 14, 100-106. https://doi.org/10.33271/mining14.01.100.

9. Sinchuk, O., Kupin, A., Sinchuk, I., Dozorenko, O., \& Krasnopolsky, R. (2020). Algorithms Design for Fuzzy Control by Power Streams in Conditions of Underground Extraction of Iron Ore. 2020 IEEE $7^{\text {th }}$ International Conference on Energy Smart Systems (ESS). 330-334. https://doi.org/10.1109/ESS50319.2020.9160168.

10. Bublikov, A. V., \& Tkachov, V.V. (2019). Automation of the control process of the mining machines based on fuzzy logic. Naukovyi Visnyk Natsionalnoho Hirnychoho Universytetu, (3), 112-118. https:// doi.org/10.29202/nvngu/2019-3/19.

11. Xu, J., Wang, Z., Tan, C., Si, L., \& Liu, X. (2018). Cutting Pattern Identification for Coal Mining Shearer through a Swarm IntelligenceBased Variable Translation Wavelet Neural Network. Sensors (Basel, Switzerland), 18(2), 382. https://doi.org/10.3390/s18020382.

12. Si, L., Wang, Z., Liu, X., Tan, C., Liu, Z., \& Xu, J. (2016). Identification of Shearer Cutting Patterns Using Vibration Signals Based on a Least Squares Support Vector Machine with an Improved Fruit Fly Optimization Algorithm. Sensors (Basel, Switzerland), 16(1), 90. https://doi.org/10.3390/s16010090.

13. Zhou, X., Wang, Z., Ji, R., \& Liu, X. (2015). A Novel Approach for Shearer Memory Cutting Based on Fuzzy Optimization Method. Advances in Mechanical Engineering, 5, 319272-319272. https://doi. org $/ 10.1155 / 2013 / 319272$.

14. Bublikov, A.V. (2019). Algorithm for fuzzification of the input value of the fuzzy control system of the executive body of the mining combine by hypsometry of coal seam. Collection of scientific works of the National Mining University, (57), 114-129. https://doi. org/10.33271/crpnmu/57.114.

15. Ge, S., Zhao, R., Li, W., Li, J., Liu, Y., \& Wang, Z. (2020). Sliding-mode control for coal shearer drum height adjustment based on variable speed reaching law. Journal of Vibroengineering, 22(8), 17821797. https://doi.org/10.21595/jve.2020.21223.

\section{Автоматизація процесу керування виконавчим органом видобувного комбайна за гіпсометрією пласта}

\section{А. В. Бубліков ${ }^{1}$, В. В. Ткачов ${ }^{1}$, Д. Л. Колосов ${ }^{1}$, Г. Грулер ${ }^{2}$, M. I. Стаднік ${ }^{3}$}

1 - Національний технічний університет «Дніпровська політехніка», м. Дніпро, Україна, e-mail: bublikov.a.v@nmu.one 2 - Ройтлінгенський університет, м. Ройтлінген, Федеративна Республіка Німеччина

3 - Вінницький національний аграрний університет, м. Вінниця, Україна 
Мета. Створення методу синтезу системи нечіткого автоматичного керування виконавчим органом видобувного комбайна за гіпсометрією вугільного пласта на основі інформаційного критерію початку присікання породи органом, за рахунок чого зменшується зольність видобутого вугілля.

Методика. 3 урахуванням особливості визначення чіткого інформаційного критерію початку присікання органом породи й закономірностей його зміни у процесі роботи видобувного комбайна, створюється алгоритм нечіткого виводу для системи нечіткого автоматичного керування органом за гіпсометрією пласта. При цьому обгрунтовуються правила нечітких продукцій, параметри функцій належності термів вихідної лінгвістичної змінної системи та нечіткі операції згідно з рекомендаціями класичного алгоритму нечіткого виводу Мамдані. Досліджується ефективність запропонованого алгоритму нечіткого виводу на основі введеного відносного показника кількості сформованих системою нечіткого керування ефективних керуючих впливів. За допомогою імітаційного моделювання здійснюється порівняльний аналіз ефективності керування органом комбайна.
Результати. У ході досліджень розроблено алгоритм нечіткого керування верхнім виконавчим органом видобувного комбайна за гіпсометрією вугільного пласта на основі визначення прямого та зворотного переходу від руйнування виконавчим органом видобувного комбайна вугілля біля покрівлі пласта до руйнування породи за допомогою статистичного аналізу струму статора двигуна приводу різання.

Наукова новизна. Уперше запропоновано метод синтезу системи нечіткого автоматичного керування виконавчим органом комбайна за гіпсометрією пласта.

Практична значимість. Запропонований у роботі метод $€$ теоретичною основою для розв'язання важливої науково-прикладної задачі автоматизації процесу керування виконавчим органом видобувного комбайна за гіпсометрією пласта з метою зменшення зольності видобутого вугілля.

Ключові слова: видобувний комбайн, алгоритм нечіткого виводу, гіпсометрія вугільного пласта, зольність вугілля

Recommended for publication by V.V.Sliesarev, Doctor of Technical Sciences. The manuscript was submitted 10.12.20. 